\section{Az elitek változása}

\section{Új megközelítések a kvantitatív adatbázisok} történetszociológiai elemzésében

A különböző módszertani eljárások alkalmazásában sok tekintetben eltérő fejlődés figyelhető meg a honi szociológia egyes területein. A jelenbeli társadalmi folyamatok vizsgálatára az elmúlt évtizedekben - részint a külföldi tendenciáknak is megfelelően (erről lásd részletesebben Lazarsfeld; Easthope; Oberschall) - egyértelmủen a kvantitatív eljárásokat részesítik előnyben a kutatók. A korábbi történeti korszakok szociológiai vizsgálata esetében azonban többnyire kvalitatív módszertani eljárásokkal találkozhatunk. Állíthatjuk ezt akkor is, ha a kliometrikus iskola törekvései nálunk is ismertté váltak (Benda 1975; Benda 1979; Eddie), ha a kvantifikáló társadalomtudományos kutatást segítő remek kézikönyv kiadására is sor került a kilencvenes években (Mawdsley-Munck), és ha ugyan nem szociológusok tollából, de kiváló történetszociológiai elemzések (Benda 2000; 2003) születtek kvantitatív módszerek alkalmazásával. A kutatási területek közötti különbség okai számosak. Az eltérés magyarázható az „egyszemélyes kutatási mủhelyek” változatlanul meglévő dominanciájával, a szociológusok többségének hagyományos idegenkedésével a matematikai-statisztikai eljárásoktól és a történetszociológiai terület jelenbeli kutatási irányzatainak (mindenekelőtt az emlékezés-emlékezetkutatásnak) elsősorban a kvalitatív megközelítéseket preferáló irányultságával. Ez az írás egy konkrét kutatás (a dualizmuskori Szombathely gazdasági elitjének vizsgálatának) példáján igyekszik bemutatni a kvantitatív módszerekben rejlő lehetőségeket a történetszociológiai kutatások számára. A tanulmány arra tesz kísérletet, hogy egy régóta ismert és a gazdasági elit vizsgálatára alkalmazott, a társadalomtörténeti kutatásokban évtizedek óta használt (Vörös; Gyáni; Szakál; Tóvári) történeti forrás, a legnagyobb adófizetőket tartalmazó virilis jegyzékek elemzésén keresztül ábrázoljon olyan módszertani lehetőségeket, amelyek a korábbiaktól eltérő szempontú vizsgálatokat is lehetővé tesznek.

Miközben a jegyzékek használatával a történeti elemzésekben gyakori eljárást alkalmazom, a szombathelyi gazdasági elit virilis jegyzékek alapján történő kutatása több összefüggésben is újszerűnek tekinthető. Egyrészt ez a vizsgálat nem csupán pár jellemzőnek tartott év adatait veti össze, hanem az összes rendelkezésre álló névjegyzéket feldolgozza. ${ }^{1}$ Másrészt a korábbi elemzésektől eltérően a virilizmus és a gazdasági elit szerkezeti változásait nem a városi, hanem a vármegyei listák adófizetőin keresztül vizsgálom. Noha már a korszakra vonatkozóan is rendelkezésre álltak virilis listák rendezett tanácsú városokról (ezek közé tartozott Szombathely), sőt virilis elemzések is születtek ilyen források alapján (Tóvári); mégsem ezeket a jegyzékeket dolgoztam fel, hanem az új értelmezést lehetôvé tevő, de mégis idegenkedéssel kezelt megyei listákat használtam. A kérdésre vonatkozó korábbi társadalomtörténeti, történetszociológiai kutatások legfóbb paradoxona az, hogy éppen azon jellemzỏ miatt negligálják ezt a forrást, amely a legtöbb elemzési lehetőséget rejti magában. A városi listákat választó kutatók legfóbb ellenérve a megyei listákkal szemben ugyanis az, hogy az egyes években eltérő számú virilist kell tekintetbe venni. (Ez abból adódik, hogy a mindenkor vizsgált város és a megye gazdasági potenciáljának folyamatos változásából adódóan az egyes években mindig eltérő számarányú városi virilis kerül fel a listákra.) Megközelítésem szerint azonban ebben a látszólagos hátrányban rejtőzik a megyei virilis listák használatának legnagyobb előnye. Az egyes évek eltérő listás adófizetőinek számai ugyanis a vizsgált település gazdasági súlyának változásaira utalnak. Időleges gazdasági recesszió esetén, amikor az adott város adófizetői a régióhoz viszonyítva alacsonyabb adóösszeggel rendelkeznek, akkor számuk is alacsonyabb lesz a listán; fordított esetben viszont a város viriliseinek számbeli növekedése lesz tapasztalható a megye legnagyobb adófizetői között. Szombathely estében például a virilisek növekvő száma párhuzamos a város növekvő népességével és gazdasági súlyával. (Az 1872-es kiinduló év 64 adófizetője helyett a századfordulóra átlagosan 100 körüli szombathelyi adózó jelenik meg a 300-as megyei virilis listákon.) Így az egyes években tekintetbe vett virilis listák hozzávetőlegesen a város ugyanolyan arányú adófizető rétegét tartalmazzák. Szombathelyi elemzésünkben tehát egy változó számú, de a városon belül többé-kevésbé azonos súlyú csoportot vizsgáltunk. ${ }^{2}$ (E megállapítások logikus folyománya, hogy minden olyan virilis elemzés, ahol a dualizmus idején minden évről ugyanolyan számú virilist vetettek össze, miközben az adott település népessége és gazdasági potenciálja jelentősen változott, nyilvánvalóan torzít. Hiszen ez esetben a városi virilis listák használatával a kutató mindig a gazdasági élet egészéhez képest különböző arányú gazdasági elitet hasonlít össze, ami alapjaiban kérdőjelezi meg az ilyen vizsgálati eredmények elfogadhatóságát. ${ }^{3}$ )

A megyei virilis listák használata a fentiek mellett a regionális központ és az egyéb területek közötti fejlődés eltérő tendenciáit is képes megvilágítani. A város és vidéke közötti eltérést ábrázolja az első táblázat.

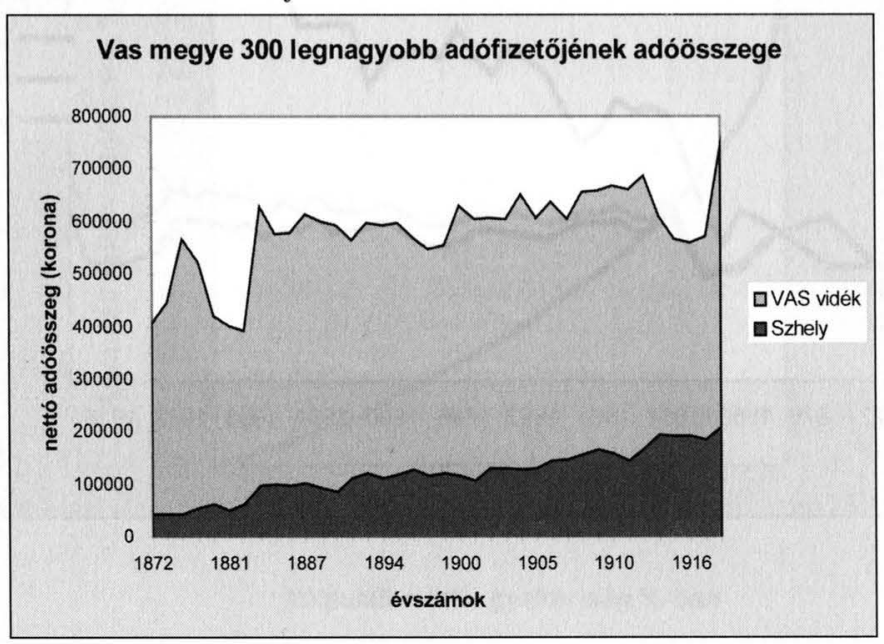

2005 - ôsz 
A Vas vármegye 300 legnagyobb adófizetőjének adóösszegét ${ }^{4}$ ábrázoló grafikon jól mutatja, hogy két kisebb jelentőségủ (az 1870-es évek végének és az 1910-es évek elejének) válságától eltekintve a megye többé-kevésbé egyenletes, de mindenképpen szolid növekedést mutat a vizsgált időszakban. A Vas vármegyei legtehetősebb polgárok adóösszegének visszafogott emelkedése még inkább láthatóvá válik, ha az itteni növekedés ütemét a dualizmus időszakának átlagos, 2,5-3\%-os növekedésével vetjük össze. Ebben az összehasonlításban a vasi vagyonos polgárok növekedése mindössze az országos növekedés felét éri el egy olyan időszakban, amelyet a tőkenövekedés és ennek koncentrációja jellemez. (Kövér; Komlos) Az adatok figyelmesebb tanulmányozásából az is kiderül, hogy a korszakban a megye legvagyonosabb polgárainak adó összegében megmutatkozó növekedés egyértelműen az egyre nagyobb súllyal jelenlévő szombathelyi adófizetők vagyonosodásával függ össze: a megye gazdasági elitjében a szombathelyi adófizetők mind számbeli, mind tőkenagyságbeli előretörése az egyetlen változás. Úgy tủnik tehát, hogy a dualizmus időszakában a gazdasági átalakulásnak azt a fázisát szemlélhetjük, amikor a gazdasági növekedés még csak a gócpontban kezdődött el, és egyelöre még nem terjedt ki az egész térségre. Minden bizonnyal ez áll annak hátterében, hogy a dinamikusan fejlődő helyi központ fejlődésével a vidék nem képes lépést tartani.

A megyei listák adataiból nyert 2. táblázat számai még inkább láthatóvá teszik Szombathely páratlan ütemủ fejlődését. Ez a grafikon a kiinduló év adóösszeg-adataihoz viszonyított elmozdulásokat ábrázolja.

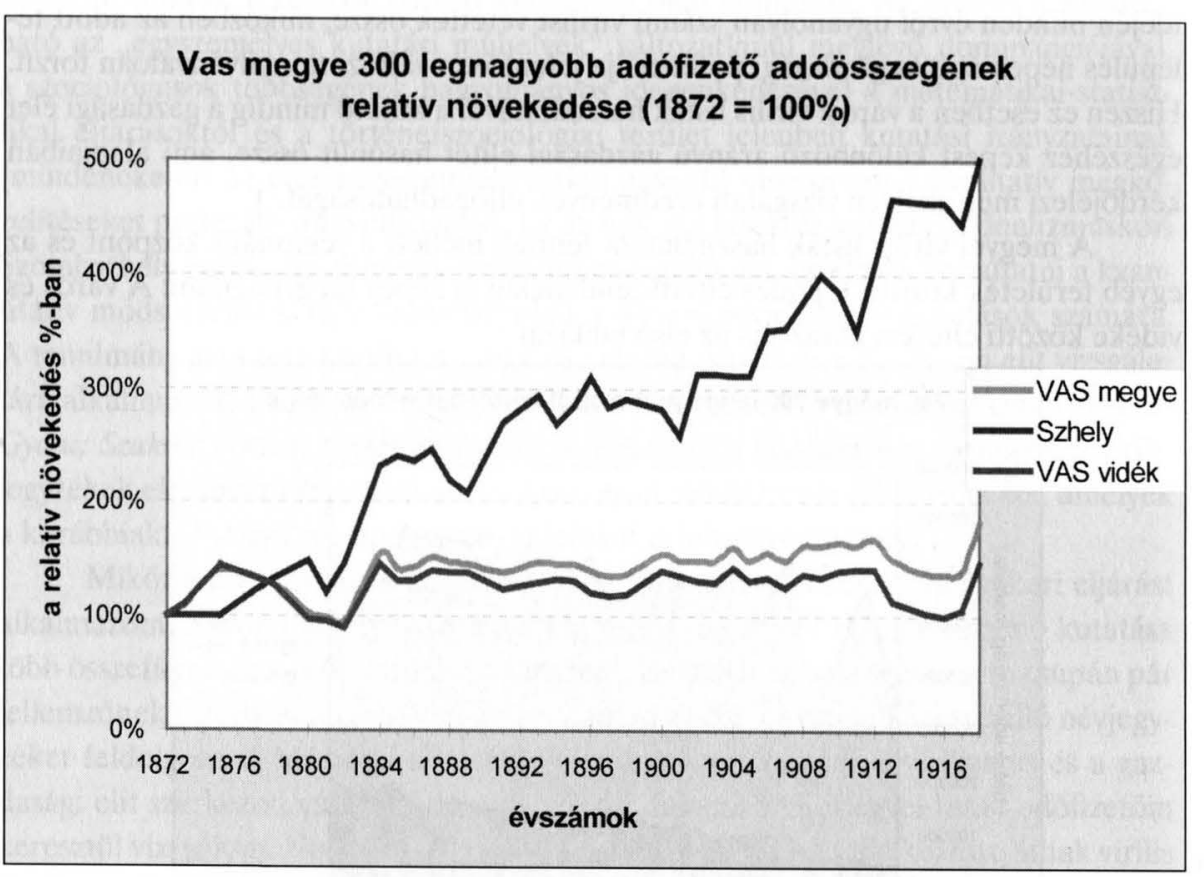
szociológiai kutatásokban nem használt matematikai-statisztikai eljárást vontam be a kvantitatív adatbázis elemzésébe, ami eddig nehezebben értelmezett átalakulások feltárását segítheti. A Lorenz-görbék elemzésén keresztül vizsgáltam, hogy a város legnagyobb adófizetőinek lendületes vagyongyarapodása mögött milyen változások történtek e csoporton belül. Történt-e lényeges átstrukturálódás Szombathely gazdasági elitjében a dualizmus időszakában? A jelentős gazdasági változásokat hozó időszakban milyen tendenciák rajzolódtak ki a tőkekoncentráció tekintetében? A szombathelyi legvagyonosabb adófizetők tőkekoncentrációjának alakulását - más forrással nem rendelkezvén - a kumulált relatív adóösszeg eloszlásából határoztam meg. Ezzel az eljárással vizsgálhatóvá vált, hogy a virilisekkel jellemzett gazdasági elit tagjai az általuk befizetett adóösszeggel az összes listára került virilis adójának milyen arányát teszik ki. Az ezt jelző, egyes évekre lebontott Lorenz-görbékkel ilyen módon Szombathely gazdasági elitjén belüli jövedelemarányok változását vizsgálhatjuk meg. A Lorenz-görbék használata rámutathat arra, hogy a dualizmus időszakában milyen átstrukturálódás történt a legnagyobb jövedelemmel rendelkezỏ polgárok egymáshoz viszonyított vagyoni helyzetében. Ezzel a statisztikai eljárással elemezhetővé válik az is, hogy az összes szombathelyi virilisre jellemző, már vizsgált (Bognár) folyamatos jövedelem-növekedésen túl létrejött-e egy szükebb elit, amelynek jövedelme messze meghaladja a többi virilis vagyoni erejét. ${ }^{5}$

Noha a kutatás a dualizmus időszakából majdnem hiánytalanul fennmaradt összes virilis jegyzéket feldolgozta, a korszak vagyoni elitjének tőkekoncentrációjában történő változások szemléltetésére elegendő a jellemző évek adatainak ábrázolása. A dualizmus időszakának elejét mutatja az 1872-es kiinduló évre vonatkozó Lorenz-görbe.

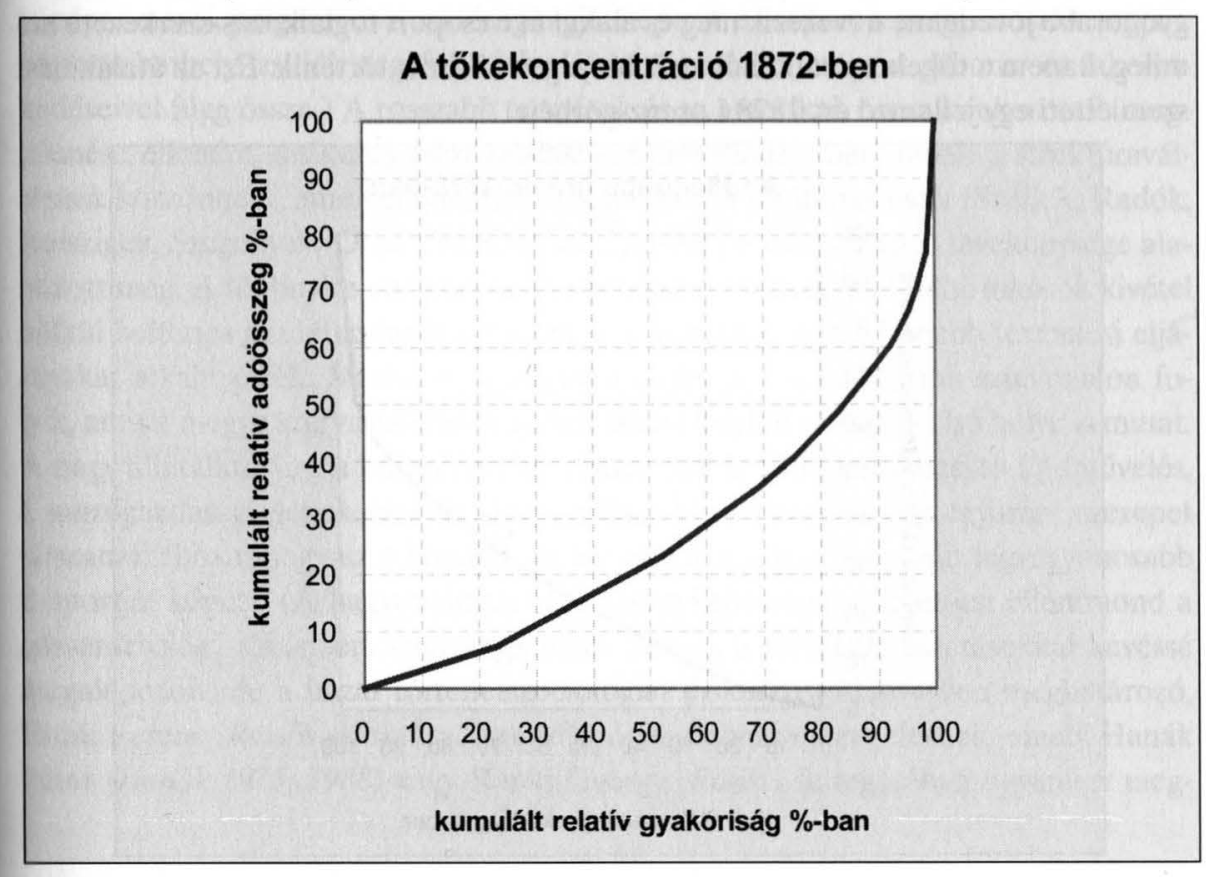

$2005-$ ősz 
A korszak elejének adatai jelentős vagyonbeli különbségeket mutatnak Szombathely legnagyobb adófizetői között. 1872-ben a város viriliseinek több mint fele $(52,3 \%)$ mindössze az adóösszeg kevesebb mint egynegyedét (23,5\%) fizeti be. A listára kerültek kevesebb mint 5\%-a $(4,6)$ pedig a legnagyobb adófizetők összadójának egyharmada $(33,5 \%)$ fölött diszponál. Tehát egy meglehetősen szűk csoport magas jövedelme élesen elkülönül a város gazdasági elitjének túlnyomó többségétől. Az átalakuló gazdasági viszonyrendszert jellemzi, hogy a dualizmus időszakának kezdetén a legnagyobb vagyonnal rendelkezők körét egyértelmủen a már a rendi társadalomban is magas státusszal bíró hagyományos elit képviselői jelentik. E szűkebb csoportba ugyanis ekkor még szinte kizárólag mindig csak a püspök, a néhány jelentős vagyonnal rendelkező földbirtokos és egy-két olyan sikerügyvéd kerül, akinek tevékenysége Vas vármegye egészére kiterjed. A jórészt a zsidóságból és a rendi társadalom egyéb, alacsonyabb státuszú csoportjaiból rekrutálódó új gazdasági elit természetesen már ekkor is a legvagyonosabb szombathelyi polgárok között található, de jövedelmük egyelöre még e vagyonos réteg alsó- és középső csoportjaiba helyezi őket. A kiinduló év adatai egyúttal azt is mutatják, hogy a város polgárságának gazdasági ereje nem annyira jelentős, hogy számottevő tőkekoncentrációt hozzon létre. Ennek következménye, hogy a város gazdasági életéhez csak részint kapcsolódó földbirtok tókeereje és a püspöki székhely vallási elitjének vagyona meghatározó jelentőségű a legvagyonosabb polgárok tőkekoncentrációja tekintetében.

Az ezt követő (az 1870-es évek végétől az 1880-as évek közepéig tartó) időszak jelentősebb átstrukturálódása változást hoz a legvagyonosabb szombathelyi polgárok tőkekoncentrációjában is. Ekkor, az 1873-as gazdasági világválság utáni időszakban gyorsan regenerálódó gazdaság eredményeinek következtében nem csupán a legvagyonosabb jövedelme növekszik meg és alakul át e csoport foglalkozás-szerkezete némileg, hanem a tőkekoncentrációban is lényeges változás történik. Ezt az átalakulást szemlélteti egy jellemző év, 1878 Lorenz-görbéje.

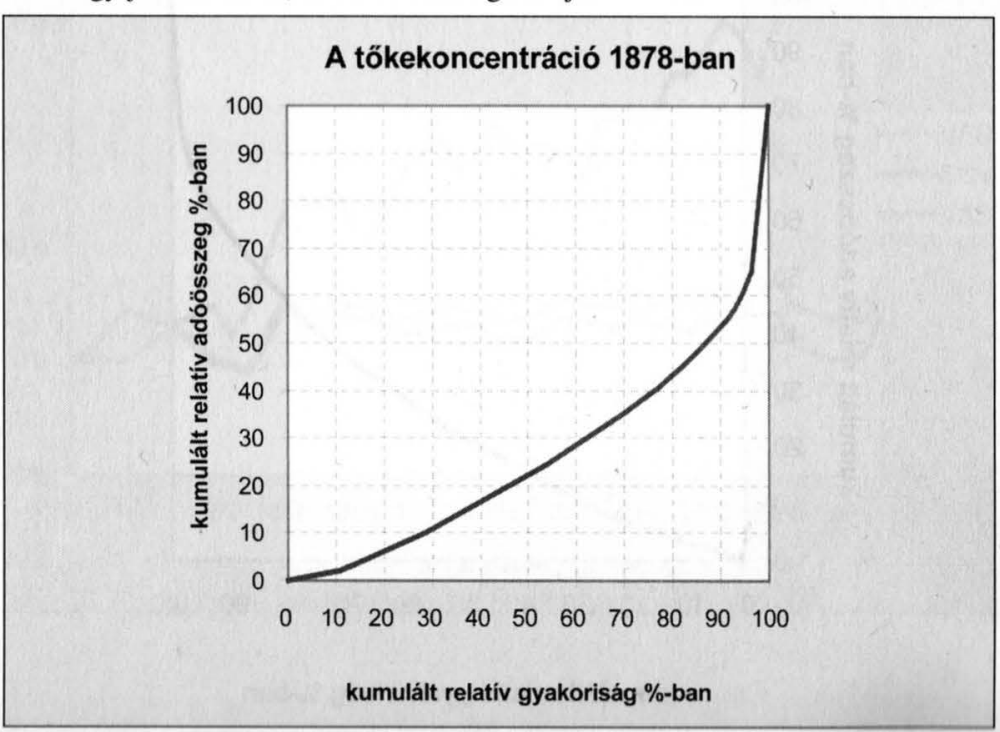

A grafikonon jól látható, hogy ennek a közel 10 éves periódusnak a döntő változása az, hogy a szombathelyi vagyoni eliten belül még inkább domináns helyzetbe kerülnek a kiemelkedően magas jövedelemmel rendelkezők: 1878-ban a szombathelyi virilisek $8,9 \%$-a a virilisek jövedelmének közel felével $(45,3 \%)$ rendelkezik! E nagy arányú tőkekoncentráció hátterében az áll, hogy az 1873-as válság különbözőképpen érintette a szombathelyi gazdasági elit egyes csoportjait. Egyrészt a zömében a legtehetősebb polgárok alsó- és középső csoportját képező kereskedők, gyárosok, iparosok voltak inkább kárvallottjai a válságnak. Ugyan 1876-ra már tartós növekedés indul meg, de 1874-es legválságosabb év hatása (amikor a szombathelyi leszámítoló bank, sok kereskedő és kisegzisztencia jut csődbe (Kunc)) az elkövetkező évtizedben is érezteti hatását. Másrészt a visszaesés alig érinti a malomipart, és a mezőgazdaságban 1875-től gyors és tartós növekedés kezdődik. E kettős folyamat végeredményeképpen a legtőkeerősebbek körében lévő, e csoporton belül is a legnagyobb jövedelemmel rendelkező földbirtokosok vagyona nagyobb mértékben növekszik, mint a legvagyonosabbak alsó- és középcsoportját képező kereskedők, iparok, gyárosok bevétele. Ez az oka annak, hogy a tőkekoncentráció növekedését nem annyira a kétségtelenül erősödő középegzisztenciák vagyonosodása határozza meg. (A szombathelyi földbirtokosok helyzetét az is javította, hogy a korábbi időszak mezőgazdasági dekonjunktúrájában a gabonafélék között az árcsökkenés a búzát érintette leginkább, körülbelül 25\%-os árcsökkenéssel, amelynek szerepe Nyugat-Dunántúlon amúgy is csekélyebb volt. (Orosz)) A földbirtok tehát megőrizte döntő szerepét abban, hogy a vagyoni eliten belül jelentősebb tőkekoncentráció alakulhasson ki. Ez a tény azonban nem csupán a hagyományos elit erejét mutatja, hiszen ekkora fokozatosan átalakul a szombathelyi illetőségü földbirtokosok köre. Ekkor már az egykori rendi társadalom középnemesei, polgárai és a zsidóság tagjai képezik e csoport legvagyonosabb tagjait. (A szombathelyi zsidók nagyfokú jelenléte e társadalmi csoport gabona- és fakereskedéseivel függ össze.) A rosszabb termések és az amerikai, orosz konkurencia megjelenése ellenére is sikeres mezőgazdasági termelés azonban annak a struktúraváltásnak köszönhető, amelyet a helyi, nemesi eredetű földbirtokosok (Széllek, Radók, Reiszigek, Szegedyek, Draskovichok, Széchenyiek) modernizációs tevékenysége alapozott meg. A többnyire pár száz holdas birtokkal rendelkező földbirtokosok kivétel nélkül belterjes gazdálkodást folytatnak és a korban a legmodernebb termelési eljárásokat alkalmazzák. Másrészt az állattenyésztés is a legmagasabb színvonalon folyik, amit a megye szarvasmarha-tenyésztésben elfoglalt országos első helye is mutat. A nagy állatállomány, a bő takàrmánytermés, sok helyütt az öntözéses földművelés, a mezőgazdasági gépek és a mütrágya széles körü elterjedtsége egyaránt szerepet játszanak abban, hogy ez a birtokos réteg ${ }^{6}$ ekkor is a gazdasági elit legvagyonosabb csoportját képezi. (A hagyományos elit versenyképessége alapvetően ellentmond a „dzsentrivilág” jól ismert sztereotípiáinak. Annak a történeti kutatásokkal kevéssé megalapozott, de a hazai történetszociológiai diskurzust alapvetően meghatározó, Erdei Ferenc „kettős struktúra” koncepcióján alapuló elképzelésnek, amely Hanák Péter (Hanák 1975; 1988) vagy Ránki György (Ránki) felfogásában ugyanúgy meg- 
jelenik, mint az álláspont legkövetkezetesebb képviselőjénél, Karády Viktornál (Karády).)

1890-es évek elején, amikor döntő átstrukturálódás történik a foglalkozás-szerkezetben ${ }^{7}$ és amely időszakra a folyamatos növekedés jellemzö, a virilisek tőkekoncentrációja is változik. Ez az átalakulás látható ennek az időszaknak egyik jellemző évét, az 1893-asat bemutató Lorenz-görbén.

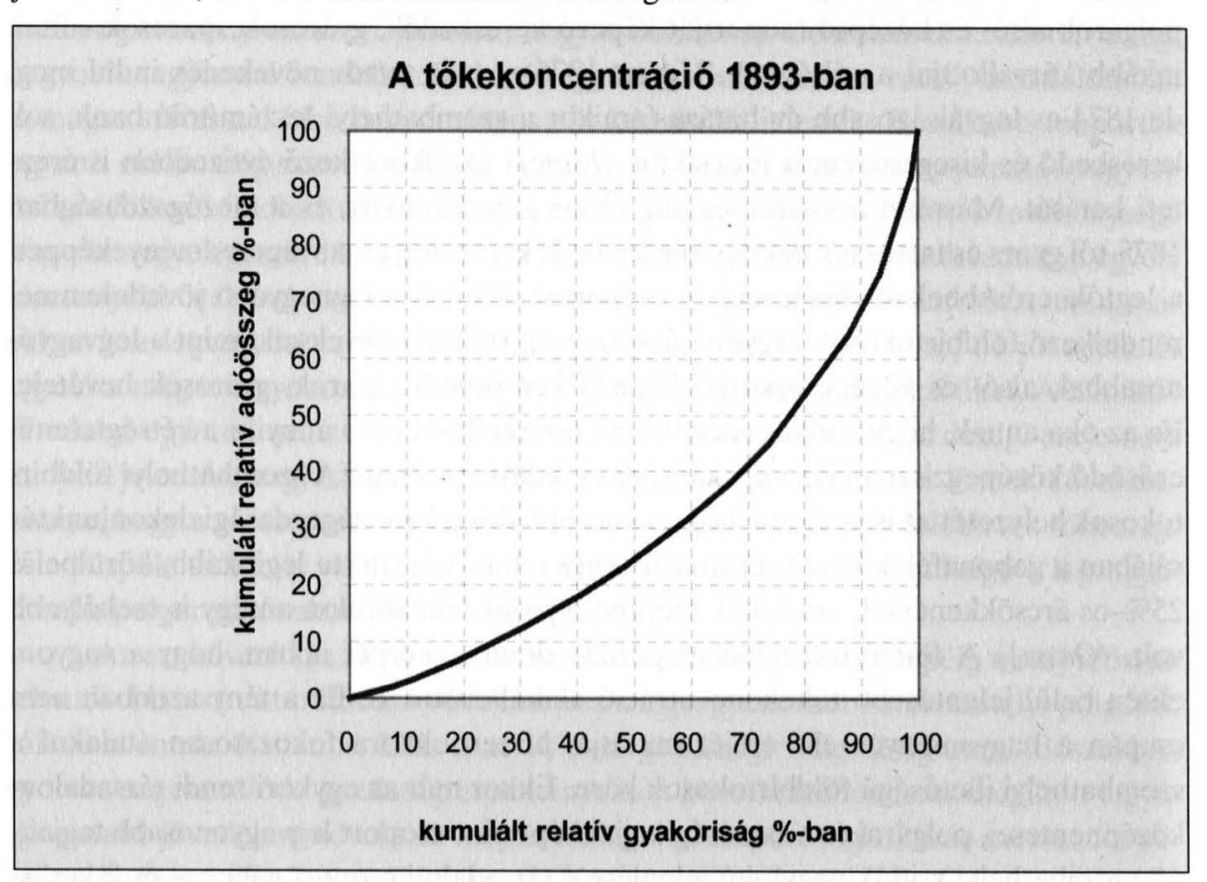

Ez az az időszak, amikor megszűnik a gazdasági eliten belül a legvagyonosabbak szűk körủ dominanciája. Természetesen kiugró vagyonok ebben az időszakban is vannak, de a vagyoni elit többsége is sokkal inkább képes felzárkózni a legnagyobb bevétellel rendelkezők mögé. Az 1890-es évektől a virilisek alsó- és középső csoportja - ami valójában a helyi társadalom felső-középosztályát jelenti - úgy erősödik meg a legvagyonosabbakhoz képest, hogy közben az utóbbiaknak is növekszik az adó összege. Ezen évek Lorenz-görbéinek tanúsága szerint a századfordulóig jellemzően a virilisek 30\%-a az összadóösszeg 15\%-ával, a felső $10 \%$ az összes kevesebb, mint 30\%-ával rendelkezik. Mivel a szombathelyi gazdasági eliten belüli elmozdulás minden részcsoport jelentős vagyonosodásával együtt történt, ez a változás a vagyoni elit alsó- és középcsoportjainak nagyon határozott előretörését jelenti. Ennek hátterében pedig az áll, hogy e csoportokban a korábbi, kevésbé vagyonos iparos, kiskereskedő, háztulajdonos réteggel szemben már egy jelentősebb vagyonnal bíró réteg alakul ki. Két foglalkozáscsoport különösen kiemelkedik e középcsoportok tőkenövekedésében. Egyrészt a szinte kivétel nélkül a zsidóságból rekrutálódó középkereskedők jövedelemnövekedése ${ }^{8}$, másrészt a hagyományos (nemesi) elit magas képzettségű tagjaiból álló pénzvilág képviselőinek vagyona ${ }^{9}$ hozza magával, hogy e rétegek jöveaz, hogy a növekedés már sokkal kevésbé egy szük elit jövedelemváltozásával függ össze, hanem egy stabil középvállalkozói réteg Szombathely gazdasági prosperitásának a letéteményese.

A következő jelentős változás már a XX. század első évtizedében játszódik le, amikor a legnagyobb szombathelyi adófizetők tőkekoncentrációja - kis eltéréssel - visszaáll a korszak elején megfigyeltekhez; mint ahogy ez az 1908-as év Lorenz-görbéjén is látható.

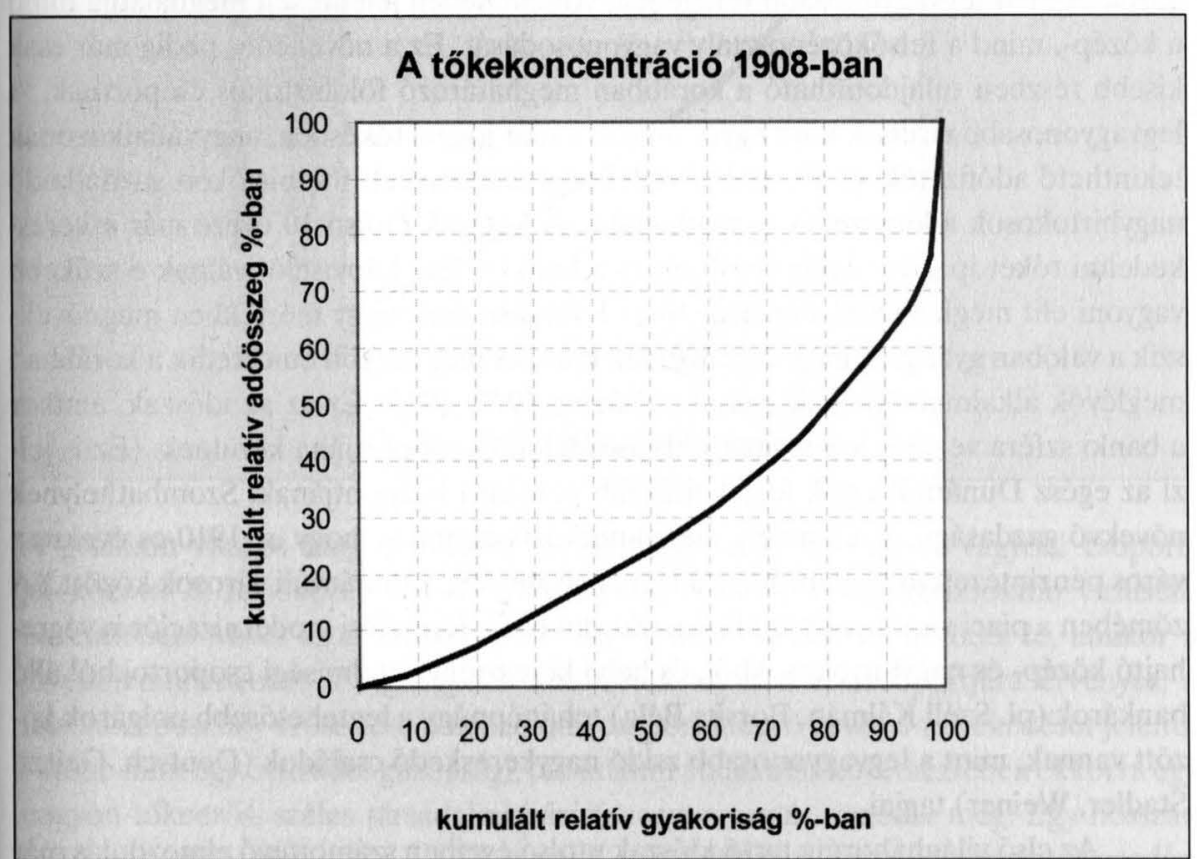

Az adatok sok tekintetben egybeesnek a kiinduló 1872-es év jellemzőivel, hiszen a legvagyonosabbak részaránya a virilisek összadójából újra növekszik. A különbséget az jelenti, hogy az alacsonyabb jövedelemmel bíró virilisek részaránya magasabb a kiinduló évekhez képest, vagyis nem csökkent jelentősen: a listások $30 \%$-a a virilisek összadójának 15\%-ának a közelében van. Egybeesés viszont, hogy a gazdasági eliten belüli legvagyonosabbak újra domináns helyzetbe kerülnek: az összes virilis mindössze alig több mint $10 \%$-a fizette be az összes adó közel $40 \%$-át $(39,7)$. A dualizmus első éveihez hasonló tőkeeloszlás mögött azonban a korszak elejétől alapvetően elütő vagyonosodási tendenciák rajzolódnak ki. Mivel erre az időszakra is az jellemző, hogy a legvagyonosabb szombathelyi adófizetők jövedelme fokozatosan növekszik, e társadalmi réteg középcsoportjának lemaradása a legvagyonosabbaktól valójában esetükben is további vagyonosodással jár együtt. Tehát az egyre inkább gazdasági központtá váló város egyre szélesebb felsőközéposztálya változatlanul fontos szerepet játszik a város és a régió gazdasági életében. Jövedelemnövekedése jelzi, hogy a 

virilisek alsó kategóriáját jelentő adófizetők, zömében a helyi középosztály tagjainak a náluk tehetősebbekhez mért vagyonosodása a dualizmus időszakában először lesz nagyobb a felsőközéposztály tagjainál. Ez a növekedés azt mutatja, hogy az első világháborúig tartó időszak végén kibővül a már jelentősebb vagyonnal rendelkezők köre, ami Szombathely regionálisan nagyon erős gazdasági potenciálját mutatja.

Az a tőkekoncentráció azonban, amely ebben az időszakban megfigyelhető a gazdasági elit legvagyonosabb rétegében, volumenében jelentősen meghaladja mind a közép-, mind a felsőközéposztály vagyonosodását. Ez a növekedés pedig már csak kisebb részben tulajdonítható a korábban meghatározó földbirtokos csoportnak. A legvagyonosabb virilisek köre egyre inkább a már joggal tőkésnek, nagyvállalkozónak tekinthető adófizetőkből áll, akik jövedelme a modernizált földbirtokon gazdálkodó nagybirtokosok adóösszegét is meghaladja. A korszak utolsó 10 évére már a kereskedelmi tőkét iparivá alakító virilisek és a banki szféra képviselői válnak e szűkebb vagyoni elit meghatározó tagjaivá. 10 év leforgása alatt nagy mértékben megnövekszik a valóban gyáripari nagyságú üzemek köre, és még inkább emelkedik a korábban meglévők alkalmazottjainak száma. (Thirring 1912; 1913) Ez az az időszak, amikor a banki szféra vezetői is a legnagyobb jövedelmủek csoportjába kerülnek. (Ez is jelzi az egész Dunántúl egyik legjelentősebb pénzügyi központjának, Szombathelynek növekvő gazdasági súlyát, amely megmutatkozik abban is, hogy az 1910-es évekre a város pénzintézeteinek alaptőkéje a legmagasabb lesz a dunántúli városok között.) A zömében a piaci viszonyokhoz alkalmazkodni tudó, termelési modernizációt is végrehajtó közép- és nagybirtokosokból, és helyi keresztény értelmiségi csoportokból álló bankárok (pl. Széll Kálmán, Borsits Béla) tehát éppúgy a legtehetősebb polgárok között vannak, mint a legvagyonosabb zsidó nagykereskedő családok (Deutsch, Geiszt, Stadler, Weiner) tagjai.

Az első világháborúig tartó időszak utolsó éveiben számottevő elmozdulás már nem történik a legvagyonosabb szombathelyi polgárok tőkekoncentrációjában. Egy lényegesebb változás azonban szükségessé teszi, hogy a legtehetősebb viriliseket egy némileg szűkebb bontásban is megvizsgáljuk. A dualizmus végét jelző időszakban ugyanis módosul a helyi társadalom legszűkebb elitjének és a felsőközéposztály vagyoni helyzetének a viszonya. Ezt az elmozdulást szemlélteti a 60 legvagyonosabb szombathelyi virilis ${ }^{10}$ tőkenagyságának arányait ábrázoló, az utolsó évekre jellemző 1913-as évi Lorenz-görbe.

A 60 legvagyonosabb tökekoncentrációja 1913-ban

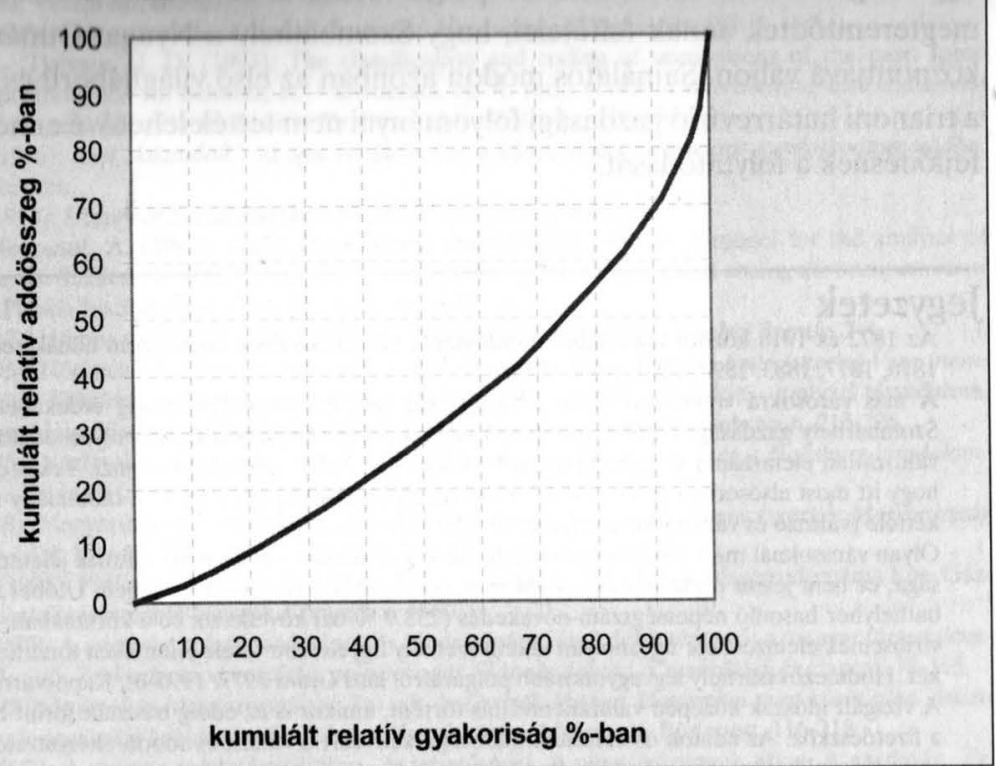

A grafikon világos kiegyenlítődést mutat a gazdasági elit egyes vagyoni csoportjai között. A felsőközéposztály jövedelme közeledett a legvagyonosabb virilisták bevételéhez. Mivel ez a változás itt is egy olyan időszakban játszódik le, amikor a jövedelemnövekedés a legnagyobb adófizetők minden részcsoportjára érvényes, a felsőközéposztály erősödése e társadalmi csoport kiugró bevétel-növekedését jelenti. A több mint egy évtizedes gazdasági, társadalmi átalakulás következtében ekkorra egy nagyon tőkeerős, széles társadalmi bázisú vagyonosodás történik meg. Egy hosszan tartó, sok tekintetben már a XIX. század első felében elinduló középosztályosodási folyamat végén alakul ki egy már regionális szinten is vagyonos, földbirtokosokból, nagykereskedőkből, bankárokból, építési vállalkozókból, gyárosokból, szállodásokból álló nagypolgári és középosztályi társadalmi csoport. Mindez a több évszázados, számottevő törések nélküli társadalomfejlődés következménye. Szombathely esetében ennek köszönhető, hogy míg más régiókban a kapitalista átalakulás éles társadalmi konfliktusokat, sőt sok esetben a társadalom erőteljes polarizálódását hozta magával, addig a Nyugat-Dunántúl új regionális központja esetében a társadalmi változás harmonikusan játszódott le a rendi társadalomból a polgári társadalomba való átmenet időszakában. Ez a dinamikus, mégis kiegyenlített átalakulás mutatkozott meg a dualizmus idejének gazdasági elitjében is. A fokozatosan változó gazdasági helyzet által szocializált nemesi birtokos, hagyományos elit éppúgy képes volt a modernitást jelentő új kihívásokra reagálni, mint a kapitalizmus létrejöttekor feltörekvő csoportok (a zsidóság, vagy a rendi társadalomban szintén alacsony státuszú egyéb rétegek) tagjai. A hagyományos elit megmaradó és a feltörekvő polgárság kialakuló versenyképessége talán a magyarázat arra, hogy a dualizmus időszakának fél évszázada alatt 
vált Szombathely egy fejlett agrárkultúrájú térség gazdasági, kereskedelmi és pénzügyi forgalmát ellenőrzỏ modern polgárvárosává. A vizsgált korszak végére tehát megteremtődtek annak feltételei, hogy Szombathely a Nyugat-Dunántúl regionális központjává váljon. Sajnálatos módon azonban az első világháború és sokkal inkább a trianoni határrevízió gazdasági folyományai nem tették lehetővé ennek a dinamikus fejlődésnek a folytatódását.

\section{Jegyzetek}

Az 1872 és 1918 közötti időszakból mindössze a következő évek adatai nem állnak rendelkezésre: 1874 Az 1872 és 1918 közötti időszakból min $1883,1890,1892,1899,1914$.

A más városokra vonatkozó virilis kutatásokkal való összehasonlíthatóság érdekében a dualizmuskori Szombathely gazdasági elitjére vonatkozó vizsgálat keretében készítettem olyan adatbázisokat is, amely Szombathely gazdasági elitjere vonatkozo vizsgálat keretében készitettem olyan adatbázisokat is, amely hogy itt most elsősorban csak a módszertani megfontolásokra térek ki, ez a tanulmány nem tartalmazza a hogy itt most elsősorban csak a módszertani megfontolásokra tére

kétféle (változó és változatlan elemszzámú) adatbázis összevetését. sága, ez nem jelent olyan komoly problémát, mint például Kaposvár esetében. Utóbbi településen Szomsága, ez nem jelent olyan komoly problèmát, mint példaul Kaposvár esetében. Utóbbi településen Szom-
bathelyhez hasonló népességszám-növekedés ( $253.9 \%$-os) következik be a korszakban, és ezért Kaposvár viriliseinek elemzésekor ugyanolyan számú személy figyelembe vétele jelentőssen torzíthatja az eredményeviriliseinek elemzésekor ugyanolyan számú személy figyelembe vétele jelentỏsen torzíthatja az eredménye-
ket. Hódmezóvásárhely legvagyonosabb polgárairól lásd Gyáni 1977; 1995-öt; Kaposváról pedig Hegedüst. ket. Hódmezővásárhely legvagyonosabb polgárairól lásd Gyáni 1977; 1995-öt; Kaposvárról pedig Hegedust. A vizsgált időszak közepén valutanemváltás történt, amikor is az eddig használt forint helyett korona let a fizetőeszzöz. Az adatok összehasonlíthatósága kedvéé

századforduló előtti (forint) adóérték megduplázásával.
A tőkekoncentráció vizsgálatánál az összes Vas vármegyei listára felkerült szombathelyi virilis adatait figyelembe vettem. Tehettem ezt azért is, mert az 1910-es évek kivételével (erre majd külön kitérünk) nem volt eltérés a város összes és 60 legnagyobb adófizetổ Lorenz-görbéje között.

Érdemes megjegyezni, hogy ezen időszak vagyoni elitjének legvagyonosabb tagját jelentő püspök jövedelme sem kizárólag a magas státuszú vallási hivatal bevételéből származik. A kiemelkedỏen magas adóérték szombathelyi püspökség földbirtokainak és az ott folyó korszerü termelési eljárásoknak is köszönhetô. A püspökség sorki (piros-tarka berni simmenthali) szarvasmarha-tenyészete pedig az ország egyik legmodernebb ilyen típusú üzeme. (Erről bővebben lásd Borovszkyt.)

A foglalkozási csoportok történeti kvantitatív adatbázisban történő kódolásának, elemzésnek problémáiról lásd: Morris, Diederiks - Tjalsma, Gribaudi - Mogoutof.

Ez a jelentőss változás mutatkozik meg az egy fổre eső adó összegében: a kereskedők az 1870-es évek utolsô helyéről a földbirtokosok és a papság képviselöi mögé kerülnek; és a pénzvilágból érkezỏ egy-két személy adataitól eltekintve a legvagyonosabb tőkés csoporttá válnak.

A pénzvilág jövedelem-növekedésének hátterében a kapitalista átalakulással megszületổ helyi bankélet áll. Ennek eredményeképpen szorulnak ki a korábbi időszak kisebb vagyonnal rendelkezỏ virilisei (a kereskedelem részeként pénzügyi tevékenységet folytató adófizetök, a helypénzbérlök), és kerülnek a legvagyonosabb polgárok közé a takarékpénztár-igazgatók, igazgató-elnökök és bankárok.

10 Ebben az összehasonlításban 1913-ban az összes szombathelyi, a Vas vármegyei 300-as listára kerülô adófizető feléről van szó.

\section{Felhasznált irodalom}

Benda Gyula (1975): New Economic History. Történeti Statisztikai Tanulmányok, 1. 261-275.

Benda Gyula (1979): Kvantifikáció és történelem (Hozzászólás Granasztói György „A történész és a mérés - egy modell korlátai" címü íráshoz) Történelmi Szemle, 22:1. 105-108.

Benda Gyula (2000): A halálozás és a halandóság Keszthelyen 1747-1849. In: Faragó Tamás - Őri Péter (szerk.) Történeti demográfiai évkönyv 2000. KSH-NKI. Budapest 122-166.

Benda Gyula (2003): A házasságok Keszthelyen 1750-1849: az átlagtól a mikrotörténelemig, avagy a léptékváltás problémája. Keszthelyi házasságkötések 1770-1849. In: Dobrossy István (szerk.) Mikrotörténelem: vívmanyok és korlátok. A Hajnal István Kör - Társadalomtörténeti Egyesület 1999. évi miskolci konferenciájának előadásai. (Rendi társadalom - polgári társadalom 12.) Hajnal István Kör - Borsod-Abaúj-Zemplén Megyei Levéltár, Miskolc, 61-81. Dezsô Múzeum, Veszprém, 163-207.

Borovszky Samu (1904): Magyarország vármegyéi és városai. Vas vármegye. Budapest, 417.

Diederiks, H. A. - Tjalsma, H. D. (1993): The classification and coding of occupations of the past: some experiences and thoughts. In: Schürer, K. - Diederiks, H. A. (ed.) (1993): Understanding and coding the occupations of the past. Max-Planck-Institut für Geschichte, Göttingen, 29-40.

Eddie, Scott M. (1996): Ami „köztudott”, az igaz is? Bevezetés a kliometrikus történetirís gondolkodásmódjába. Csokonai, Debrecen.

Easthope, Gary (1974): History of Social Research Methods. Longman, London.

Gribaudi, M. - Mogoutof, A. (1993): Social stratification and complex systems: a model for the analysis of relational data. In: Schürer, K. - Diederiks, H. A. (ed.) (1993): Understanding and coding the occupations of the past. Max-Planck-Institut für Geschichte, Göttingen, 53-74.

Gyáni Gábor (1977): Hódmezővásárhely legnagyobb adófizetői (1888 - 1941). Történelmi Szemle, 3-4.

Gyáni Gábor (1995): Hódmezővásárhely társadalma 1920-1941 között. In: Á. Varga László (szerk.) Vera (nemcsak) a városban. Tanulmányok a 65 éves Bácskai Vera tiszteletére. Rendi társadalom - polgári társadalom, Supplementum. Hajnal István Kör - Társadalomtörténeti Egyesület, Csokonai, Debrecen, 213-226.

Hanák Péter (1975): Vázlatok a századelô magyar társadalmáról. In: uô:: Magyarország a Habsburg-birodalomban. Gondolat, Budapest, 341-405.

Hanák Péter (1988): Magyarország társadalma a századforduló idején. In: Mucsi Ferenc (szerk.): Magyarország története 1890-1918, I. kötet, Akadémiai, Budapest, 441-448.

Jegedüs Sándor (1995): Virilizmus Kaposváron 1888- 1944. Szakdolgozat. ELTE Bölcsészettudományi Kar, Gazdaság- és Társadalomtörténeti Tanszék Könyvtára, 4860.

Karády Viktor (1997): A zsidóság polgárosodásának és modernizációjának főbb tényezöi a magyar társadalomtörténetben. In: uổ: Zsidóság modernizáció, polgárosodás (Tanulmányok). Cserépfalvi, Budapest. 78-113.

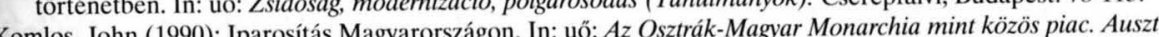
Komlos, John (1990): Iparositás Magyarországon. In: uô: Az Osztrak-Magyar Monarchia mint kozos
ria-Magyarország gazdasági fejlödése a tizenkilencedik században. Maecenas, Budapest, 116-218.

ria-Magyarország gazdasági fejlödese a tizenkilencedik szazzadban. Maecenas, Budapest, 116-218. Kövér György (1982): A magyar gazdaságpolitika - és lehetōségei. A pénzszékrénye

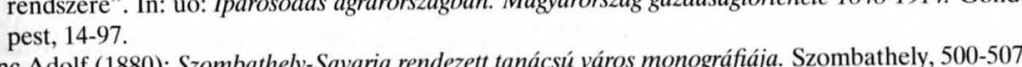
Kunc Adolf (1880): Szombathely-Savaria rendezett tanácsú város monográfiaja. Szombathely, 500-507. Lazarsfeld, Paul F. (1962): Th Sociology of Empirical Social Research. American Sociological Revien

Mawdsley, Evan - Munck, Thomas (1996): Számítógép a történettudományban. Osiris, Budapest. Morris, R. J. (1993): Fuller values, questions and contexts: occupations coding and the historian. In: Schürer, K. - Diederiks, H. A. (ed.) (1993): Understanding and coding the occupations of the past. Max-Planck-Institu für Geschichte, Göttingen, 5-22.

Oberschall, Anthony (ed.) (1972): The Establishment of Empirical Sociology. Studies in Continuity, Discontinuity and Institualization. Harper and Row, New York.

Orosz István (1988): Szerkezeti változások a XIX. századi magyar mezögazdaságban. Elöadások a Történettudományi Intézetben 10. Budapest, 1988. 7.

Ránki György (1988): Die Entwicklung des ungarischen Bürgertums vom späten 18. zum frühen 20. Jahrhundert. In: Jürgen Kocka (hrsg.): Bürgertum im 19. Jahrhundert. Deutschland im europäischen Vergleich. Band 1 Deutscher Taschenbuch Verlag, München, 247-265.

zzakál Gyula (1987): Gondolatok a győri gazdasági elit történetéről 1900 és 1940 között. Gyốri Tanulmányok, 8. $27-38$.

Thirring Gusztáv (szerk.) (1912): A jelentékenyebb ipari vállalatok felsorolása - 1911. In: uő:: A magyar városok statisztikai évkönyve. I. évfolyam. Budapest Székesfôváros Házinyomdája, Budapest, 309.

Thirring Gusztáv (szerk.) (1913): 20-nál több segédszemélyzetet alkalmazó bánya- és iparvállalatok községenként (Szombathely). In: Magyar Statisztikai Közlemények. Új Sorozat. 48. Kötet. II. 1910. évi népszámlálás. Athenaeum, Budapest, 982-985.

Tóvári Judit (1993): A városi elit Miskolcon 1872-1917. Kandidátusi értekezés. ELTE Bölcsészettudományi Kar, Gazdaság- és Társadalomtörténeti Tanszék Könyvtára, 4958.

V̈̈rös Károly (1979): Budapest legnagyobb adófizetôi 1873-1917. Akadémiai, Budapest. 